\title{
THE SINGLE CURRENCY FOR ISLAMIC NATIONS: DO HETEROGENEITIES MATTER?
}

\author{
Memet Agustiar \\ Department of Economics and Business, University of Tanjungpura, Indonesia. \\ Email: memetagustiar@gmail.com
}

\begin{abstract}
The purpose of this study is to assess the readiness of 44 OIC member countries to form a currency union and to test whether the Optimum Currency Area (OCA) criteria remain relevant to a large region like the OIC. Large geographic size is subject to socio-economic and geographic disparities. This study employs the OCA-index to estimate the degree of readiness of the OIC to form a currency union. Five selected criteria -business cycle synchronization, trade openness, inflation similarity, the size of the economy, and distance - were employed to determine the OCA using Ordinary Least Squares regression. The findings of this study estimate that 63 percent of pairs of countries in the OIC are ready to form a currency union. The selected OCA's criteria present the best-fit variable in explaining the OCA for the OIC. This paper verifies that economic and geographic heterogeneities are not the main obstacle to forming a currency union. This study provides an important contribution to the theory of OCA primarily in clarifying the application of the OCA conditions in a large observation like the OIC, which comprises many countries and many blocks.
\end{abstract}

Keywords: Optimum Currency Area; OIC; Common Currency; Monetary Integration. JEL Classification: F36; F33; F36.

Received : September 16, 2018

Revised : October 08, 2018

Accepted : November 28, 2018 


\section{INTRODUCTION}

Most of the studies related to the Optimum Currency Area (OCA) assess the readiness of countries to form a currency union within a particular economic bloc, such as the Gulf Countries Council (GCC), the Association of South East Asian Nations (ASEAN), the Economic Community of Western African States (ECOWAS) and others. Since the studies cover a large geographical size like the Organization of Islamic Cooperation (OIC), which consists of 57 member countries and at least nine economic blocs, an interesting question is the extent to which the OCA theory is able to provide a comprehensive explanation for such an observation. For example, what is the optimal size of a currency union fit the criteria of symmetry? Large geographical size is sensitive to social, economic and geographic heterogeneity. Ex-ante OCA criteria theoretically require symmetry, synchronization, convergence, and similarity of shock in output and price as necessary conditions (De Grauwe, 2006).

Islamic countries acknowledge that forming a currency union was one of the strategic agenda items planned a half-century ago (Bacha, 2006). An initial assignment was planned in 1945 by twenty-two Islamic nations, which were affiliated in North Africa, and the Middle East (MENA) to form a single currency called the Dinar Arab (Kamar, 2004). Six Gulf Cooperation Council (GCC) countries declared a target date to form a single currency called the 'Khallegi' in 2010 ', which was followed by the proposal for a monetary union in 2015 by the ECOWAS (Khan, 2009). Unfortunately, neither was implemented and now require re-planning. Three Islamic nations in ASEAN have made a significant contribution in proposing the ASEAN Monetary Unit (AMU) that was designed as a parallel currency for the ASEAN Single currency (Falianty, 2006). One of the initial signs of progress was the promotion of the Trade Preferential System (TPS) within OIC member countries that came into force in 2009 (Lee, 2011).

The OIC has made significant progress during the last two decades. The OIC share in the world's GDP increased sharply from only seven percent in 2000 to almost 20 percent in 2013 (SESRIC, 2015). Intra trade among the OIC member countries reached 15 percent of the total OIC exports and increased more than five times during the last two decades. Islamic countries that were classified as lowincome countries by the World Bank dropped from 22 countries in 2000 to only four countries in 2013 (World Bank, 2015).

The OIC economies experience a wide social and economic gap (Table 1) with some Islamic countries enjoying a GDP per-capita of more than US $\$ 50,000$, while others remain below US\$1,000. Eleven countries have a GDP of above US $\$ 50,000$, whereas seven countries are still below US\$5,000. Eight OIC member countries are grouped in the countries with the lowest Human Development Index in the world. The geographic dispersion of the OIC area is relatively extreme. The largest distance from the west part (Mauritania, Africa) to the east part (Brunei Darussalam) is 16,000 kilometres. Two hundred and forty-four pairs of countries have a range distance of more than 7,000 kilometres (Table 1). 
Table 1.

Economic and Geographic Heterogeneity in OIC

\begin{tabular}{|c|c|c|c|c|}
\hline Gap & GDP Gap & GDP per-capita gap & HDI gap & Geographic Dispersal \\
\hline High & $\begin{array}{l}\text { GDP between } \\
\text { US } \$ 500,000 \text { and } \\
\text { US } \$ 2,3000,000 \\
\text { (11 countries) }\end{array}$ & $\begin{array}{l}\text { GDP per-capita } \\
\text { between US } \$ 50,000 \\
\text { and US } \$ 88,000 \\
\text { (5 countries) }\end{array}$ & $\begin{array}{l}\text { HDI between } \\
0.7 \text { and } 0.9 \\
\text { (20 countries) }\end{array}$ & $\begin{array}{c}\text { The range of distance } \\
\text { between } 7,000 \mathrm{~km} \text { and } \\
16,000 \mathrm{~km} \text {. } \\
\text { (244 pairs of countries) }\end{array}$ \\
\hline Low & $\begin{array}{l}\text { GDP between } \\
\text { US } \$ 1,400 \text { and } \\
\text { US } \$ 5,000 \\
\text { (7 countries) }\end{array}$ & $\begin{array}{c}\text { GDP per-capita } \\
\text { between US } \$ 600 \text { and } \\
\text { US } \$ 1,000 \\
(5 \text { countries })\end{array}$ & $\begin{array}{l}\text { HDI between } 0.3 \\
\text { and } 0.5 \\
\text { (7 countries) }\end{array}$ & $\begin{array}{l}\text { The range of distance } \\
\text { below 2,000 km. } \\
\text { (167 pairs of countries) }\end{array}$ \\
\hline
\end{tabular}

Sources: SESRIC (2015)

Almost all the OIC member countries are already in the stages of implementing a common market. This means that the opportunity for the OIC to implement a monetary union is just one step away. Although a common market within the OIC has become an important precondition for the formation of a single currency, this is complicated by the socio-economic and geographic dissimilarities. This paper tries to assess the feasibility of 44 OIC member countries to form a currency union using the OCA-index. This paper employed five independent criteria - business cycle synchronization, trade openness, inflation similarity, the size of an economy, and the distance against the OCA-index. The structure of this paper is organized as follows. Section II presents the literature review. Section III provides the methodology of the estimation. Section IV discusses the findings of this study, and the last section provides the conclusion and recommendations.

\section{LITERATURE REVIEW}

Robert Mundell (1961, p. 658), the founder of OCA theory, proposes 'ex-ante' conditions that countries may join a monetary union. He offers non-exchange rate means for the adjustment mechanism under a balance of payment disequilibria through factors mobility. Factor mobility, primarily labour mobility, can maintain the internal balance by the movement of factors of production away from the deficit region to the surplus region. He also cited that a similar pattern and the direction of shocks are a key requirement for the OCA. The following proponents, McKinnon (1963) and Kenen (1969), extend the other OCA criteria, which consider the degree of openness, the size of the economy, and product diversifications. According to McKinnon (1963), openness is associated with the efficient allocation of resources and symmetry of the exchange rate. The size of the economy indicates the capacity of the countries to make adjustments facing the balance of payment disequilibrium through foreign reserve channels. Product diversification - no single dominant product of export - is the main driver to accelerate monetary unification (Kenen, 1969). The OCA criteria are now developing many variances that involve inflation similarity, financial-market integration, and fiscal integration (Silva and Tenreyro, 2010). 
OCA eliminates the exchange rate risk by sharing in a common currency. Within the member countries, exchange rates are irrevocably pegged but fluctuate jointly vis-à-vis other currencies (De Grauwe, 2006). Members of the union may enjoy benefits, such as more efficient trade through the reduction of transaction costs, greater factor mobility, and co-movement of shocks (Horvart, 2003). OCA also has costs, such as the loss of monetary autonomy, and loss of exchange rate sovereignty (Mundell, 1961; Mongelli, 2008). OCA reshapes the monetary structure from one country-one currency to a multinational one market-one money (Rose, 2000; Alesina and Barro, 2001).

Frankel and Rose (1998) criticise the old-OCA theory by considering that the OCA-criteria are endogenous (ex-post). The countries that fail to fulfil ex-ante criteria may attain the OCA criteria ex-post. The pieces of evidence from Eurozone exhibit the co-movement of shock and substantial trade growth after they join the union (Gouveia and Correia, 2013). Krugman (1991) specifies that asymmetry emerges in times of openness, resulting from increasing economies of scale, which lead to regional specialization, and regional concentration of industries, which then drive regional economic imbalance. The symmetric and asymmetric cycles, therefore, are not static in nature, but may fluctuate in any circumstances, closed or open economies, ex-ante or ex-post.

Studies supporting the feasibility of a single currency in Islamic countries produce mixed results. Observing 24 OIC countries, Lee (2011) finds that it is only feasible for Jordan, Tunisia, Syria, Gabon, Brunei and the UAE to join the OCA. Laaban and Limas (2002) find that GCC countries are far from a currency union. Ruzita, Hamid, and Norma (2011) identify only 11 commodities out of 50 observed commodities that could be integrated within the OIC. The weak integration within the OIC is due to the limitation of product diversification, which polarizes on gas and oil. The rapid contemporary development of the Gulf countries means that it is not possible to form a currency union yet (Raison, 2011). However, opposite findings considered that a monetary union is feasible for the GCC (Kandil and Trabelsi, 2010; Bali and Osman, 2008). Bacha (2006) find that it is more feasible for the GCC to form a currency union than for the Agadir Nation (Jordan, Tunisia, Egypt, and Morocco).

The relationship between currency and geography has been documented in the OCA literature. By definition, the optimum currency area is a regional neighbouring area. How large should a single currency be? Ghosh and Wolf (1994) said that restricting monetary unions to geographically neighbouring areas implies high costs. The cost is the stabilization cost to maintain a single currency. They estimate that the stabilization costs of a single currency in the Euro area reaches $2.5 \%$ of GDP each year. Some studies identified that distance is strongly associated with the trade intensity, but the correlation may follow different directions depending on how it is proxied (Gouveia and Correia, 2013; Frankel and Rose, 1997).

\section{METHODOLOGY}

This study develops an OCA-index to estimate the readiness of OIC members in forming a currency union. This study follows the OCA-index developed by Bayoumi and Eichengreen (1997, p. 764); rewritten as follows: 


$$
\text { OCA_index }=S D\left(\Delta \log e_{i j}\right)
$$

where, SD denotes standard deviation, $\Delta \log \mathrm{e}_{\mathrm{ij}}$ is the logarithm of the standard deviation of a change in the nominal exchange rate in end-years between country $\mathrm{i}$ and country $\mathrm{j}$. The study follows the classification from Bayoumi and Eichengreen (1997), which categorizes three levels of feasibility. One is the prime converged countries (the index values range from zero to less than 0.025 ), second is the converging countries (the index values range from $0.025-0.077$ ), and the last is little-converged countries (the index values are more than 0.077).

This study estimates the Ordinary Least Squares (OLS) of multiple regression models to explain the variants of OCA. This study employs five OCA determinants - business cycle synchronization, trade openness, the size of the economy, inflation similarity, and the distance. This study observes 964 pairs of countries, which derives from the combination of 44 OIC members. To compute the OLS regression estimation, this study detects the data normality using the Kolmogorov-Smirnov Test (K-S test), multicollinearity using Pearson Correlation, and heteroscedasticity using the White-test.

The multiple regression is as follows:

$$
\begin{aligned}
S D\left(\Delta \log e_{i j}\right)= & \alpha+\beta_{1} S D\left(B C S_{i j}\right)+\beta_{2} T R A D E_{i j}+\beta_{3} S I Z E_{i j}+ \\
& \beta_{4} I N F_{i j}
\end{aligned}
$$

where SD $\left(\Delta \log e_{\mathrm{ij}}\right)$ is the logarithm of the standard deviation of a change in the nominal exchange rate in end-years between country $i$ and country $j$.

$$
B C S=S D\left(\frac{Y i t}{Y j t}-\frac{Y i, t-1}{Y j, t-1}\right)
$$

$S D\left(B C S_{i j}\right)$ is output disturbances as the logarithm of the standard deviation of the difference of relative output in the two countries.

$$
\operatorname{TRADE}_{i j}=(x+m)_{i}+(x+m)_{j}
$$

$T R A D E_{i j}$ Is the means of the sum of export $(\mathrm{x})$ and import $(\mathrm{m})$ in the two countries.

$$
I N F=\frac{\left(C P I_{i(t+1)}-C P I_{i t}\right)}{C P I_{i t}}-\frac{\left(C P I_{j(t+i)}-C P I_{j t}\right)}{C P I_{j t}}
$$

INF is inflation similarity. CPI is the consumer price index measured by means of the difference in consumer price index between two countries:

$$
S I Z E_{i j}=\frac{\log (G D P i+G D P j)}{2}
$$

SIZE is the GDP in the constant price in US Dollars measured by the logarithm of the sum of total output $\left(\mathrm{GDP}_{\mathrm{ij}}\right)$ between two countries. GDP is the Gross Domestic Product at the current price. 


$$
\operatorname{DISTANCE}=\log \left(\mathrm{km}_{i} \rightarrow \mathrm{km}_{j}\right)
$$

DISTANCE is the distance range between two countries measured in kilometres $(\mathrm{km})$.

The source of the data is available from The Statistical, Economic and Social Research and Training Centre for Islamic Countries (SESRIC): https://www. sesrtcic.org. Distance data were retrieved from http://www.distancefromto.net/. Of the 57 Islamic countries, 44 are observed in this study, which employs serial data from 1990 to 2015.

\section{RESULT AND FINDING}

\subsection{OCA Index between Countries}

The study finds that 63 percent of 946 OIC pairs of countries are classified as prime converged and converging countries. Only 37 percent of which are not feasible (see Table 2). This result is relatively balanced compared with previous studies. In Europe, for example, only 71 percent of 14 European countries were nominated as prime converged and converging countries when it was assessed using the OCAindex (Bayoumi and Eichengreen, 1997). The United Kingdom, France, and Italy fall into the little-converged countries. So far, no economic blocs successfully met full prime convergence when they started forming a currency union.

The specific finding from this study shows that 60 country pairs with OCA indexes are equal to zero. The OCA-indexes equal to zero indicate perfect symmetry and stability of exchange rate. These 60 country pairs are located in the GCC, West Africa, and Central Africa. The GCC bloc has pegged its currencies on a permanent basis with the U.S. Dollar for nearly 25 years, except Kuwait (OIC, 2012). Central Africa and West Africa have pegged their currency to the CFA Franc since 1945 (Uzonwanne, 2012). These three blocks are the replication of the so-called quasi-monetary union (Saidi and Scacciavillani, 2010).

Table 2.

Classification of the Feasibility of Optimum Currency Area in Islamic Nations

\begin{tabular}{lccc}
\hline $\begin{array}{l}\text { Classification by OCA- } \\
\text { Index }\end{array}$ & Classification of Countries & $\begin{array}{c}\text { Numbers of } \\
\text { Country Pairs }\end{array}$ & Percent \\
\hline $0.00-0.025$ & Prime converged countries & 357 & $38 \%$ \\
$\bullet 0.0000$ & & -60 & \\
$-0.0001-0.02490$ & Converging countries & -297 & \\
$0.025-0.077$ & Little converged countries & 237 & $25 \%$ \\
$0.077-2.95$ & & 352 & $37 \%$ \\
Total & & 946 & 100 \\
\hline
\end{tabular}

Source: Author calculation. 
Table 3.

The Degree of Integration among OIC Members (Calculated by the OCA-Index)

\begin{tabular}{|c|c|c|c|c|c|c|}
\hline Number & Countries & $\begin{array}{c}\text { SD } \\
(\Delta \log \mathrm{e})\end{array}$ & $\begin{array}{c}\text { Prime } \\
\text { Converged } \\
\text { to } \\
\text { (countries) }\end{array}$ & $\begin{array}{c}\text { Converging } \\
\text { to } \\
\text { (countries) }\end{array}$ & $\begin{array}{c}\text { Little } \\
\text { Converged } \\
\text { to } \\
\text { (countries) }\end{array}$ & Classification \\
\hline 1 & Comoros & 0,0192575 & 28 & 5 & 10 & Prime \\
\hline 2 & Guinea & 0,0202606 & 28 & 5 & 10 & Prime \\
\hline 3 & Mauritania & 0,0206014 & 28 & 5 & 10 & Prime \\
\hline 4 & Uganda & 0,0239057 & 28 & 6 & 9 & Prime \\
\hline 5 & Jordan & 0,0194135 & 28 & 5 & 10 & Prime \\
\hline 6 & Kuwait & 0,0220617 & 28 & 5 & 10 & Prime \\
\hline 7 & Pakistan & 0,0183260 & 28 & 5 & 10 & Prime \\
\hline 8 & Indonesia & 0,0231681 & 28 & 6 & 9 & Prime \\
\hline 9 & Bangladesh & 0,0111122 & 27 & 6 & 10 & Prime \\
\hline 10 & Maldives & 0,0172750 & 27 & 6 & 10 & Prime \\
\hline 11 & Morocco & 0,0341316 & 25 & 10 & 8 & Prime \\
\hline 12 & Gambia & 0,0425762 & 24 & 11 & 8 & Prime \\
\hline 13 & Benin & 0,0259512 & 23 & 11 & 9 & Prime \\
\hline 14 & Burkina Faso & 0,0259522 & 23 & 11 & 9 & Prime \\
\hline 15 & Cameroon & 0,0259522 & 23 & 11 & 9 & Prime \\
\hline 16 & Chad & 0,0259512 & 23 & 11 & 9 & Prime \\
\hline 17 & Cote D'Ivoire & 0,0259522 & 23 & 11 & 9 & Prime \\
\hline 18 & Gabon & 0,0259522 & 23 & 11 & 9 & Prime \\
\hline 19 & Mali & 0,0259522 & 23 & 11 & 9 & Prime \\
\hline 20 & Niger & 0,0259522 & 23 & 11 & 9 & Prime \\
\hline 21 & Senegal & 0,0259522 & 23 & 11 & 9 & Prime \\
\hline 22 & Togo & 0,0259522 & 23 & 11 & 9 & Prime \\
\hline 23 & Lebanon & 0,0270948 & 23 & 11 & 9 & Prime \\
\hline 24 & Guinea-Bissau & 0,0506465 & 17 & 18 & 8 & Prime \\
\hline 25 & Bahrain & 0,0000000 & 15 & 18 & 10 & Prime \\
\hline 26 & Oman & 0,0000000 & 15 & 18 & 10 & Prime \\
\hline 27 & Qatar & 0,0000000 & 15 & 18 & 10 & Prime \\
\hline 28 & Saudi Arabia & 0,0000000 & 15 & 18 & 10 & Prime \\
\hline 29 & Syria & 0,0000000 & 15 & 18 & 10 & Prime \\
\hline 30 & UAE & 0,0000000 & 15 & 18 & 10 & Prime \\
\hline
\end{tabular}


Table 3.

The Degree of Integration among OIC Members

(Calculated by the OCA-Index) (Continued)

\begin{tabular}{lcccccc}
\hline Number & Countries & $\begin{array}{c}\text { SD } \\
(\Delta \mathbf{l o g} \text { e) }\end{array}$ & $\begin{array}{c}\text { Prime } \\
\text { Converged } \\
\text { to } \\
\text { (countries) }\end{array}$ & $\begin{array}{c}\text { Converging } \\
\text { to } \\
\text { (countries) }\end{array}$ & $\begin{array}{c}\text { Little } \\
\text { Converged } \\
\text { to } \\
\text { (countries) }\end{array}$ & Classification \\
\hline 31 & Algeria & 0,0659396 & 5 & 30 & 8 & Converging \\
32 & Afghanistan & 0,0747822 & 5 & 30 & 8 & Converging \\
33 & Guyana & 0,0539186 & 7 & 28 & 8 & Converging \\
34 & Sierra Leone & 0,0591093 & 6 & 28 & 9 & Converging \\
35 & Malaysia & 0,0995491 & 2 & 21 & 20 & Converging \\
36 & Iraq & $14,683,098$ & 0 & 0 & 43 & Little \\
37 & Egypt & $12,532,468$ & 0 & 0 & 43 & Little \\
38 & Libya & 0,3275067 & 0 & 0 & 43 & Little \\
39 & Mozambique & $29,467,032$ & 0 & 0 & 43 & Little \\
40 & Tunisia & $28,037,246$ & 0 & 0 & 43 & Little \\
41 & Turkey & 0,5781454 & 0 & 0 & 43 & Little \\
42 & Iran & 0,1587881 & 1 & 2 & 40 & Little \\
43 & Brunei & 0,1595696 & 1 & 2 & 40 & Little \\
44 & Nigeria & 0,1109377 & 1 & 9 & 33 & Little \\
\hline
\end{tabular}

Source: Author calculation. SD $(\Delta \log$ e $)$ is OCA-index.

\subsection{OCA Index Among Blocs}

Table 3 shows how far a country is capable of integration with other countries. No country is able to integrate with all countries. Only nine countries - Indonesia, Pakistan, Bangladesh, the Maldives, Comoros, Guinea, Mauritania, Jordan, and Kuwait - succeeds in achieving maximum integration with 28 countries of the 44 observed countries. Five countries - Afghanistan, Algeria, Sierra Leone, Guyana, and Malaysia - are dominant in the converging category. These countries may potentially move to the prime convergence category in the future. In contrast, six countries - Egypt, Libya, Mozambique, Tunisia, Turkey, and Iraq - do not integrate with all countries. Egypt, Libya, Iran, and Iraq experience internal political instability. Turkey, Tunisia, and Brunei Darussalam have poor OCA-indexes due to their exchange rate movement appreciating during the last decade, which is opposite to the depreciation trend that coincides with the majority of the Islamic nations. 
Table 4.

Integration among Blocs in the OIC

\begin{tabular}{|c|c|c|c|c|c|}
\hline & $\begin{array}{l}\text { Arab (Middle } \\
\text { East) }\end{array}$ & Africa & ASEAN & $\begin{array}{c}\text { South } \\
\text { America }\end{array}$ & South Asia \\
\hline \multirow{3}{*}{$\begin{array}{l}\text { Arab (Midde } \\
\text { East) } \\
n=12\end{array}$} & $\mathrm{P}(60)^{*}$ & $\mathrm{P}(73)$ & $\mathrm{P}(9)$ & $\mathrm{P}(2)$ & $\mathrm{P}(26)^{* *}$ \\
\hline & $C(12)$ & C (96) & $C(2)$ & $C(9)$ & $C(8)$ \\
\hline & L (38) & L (95) & $\mathrm{L}(23)$ & L (2) & L (5) \\
\hline \multirow{3}{*}{$\begin{array}{l}\text { Africa } \\
\mathrm{n}=24\end{array}$} & & $\mathrm{P}(272)^{*}$ & $\mathrm{P}(18)$ & $\mathrm{P}(4)$ & $\mathrm{P}(45)^{* *}$ \\
\hline & & C (78) & C (19) & C (15) & $C(27)$ \\
\hline & & L (198) & L (39) & $\mathrm{L}(4)$ & $\mathrm{L}(20)$ \\
\hline \multirow{3}{*}{$\begin{array}{l}\text { ASEAN } \\
\mathrm{n}=3\end{array}$} & & & $\mathrm{P}(2)$ & $\mathrm{P}(0)$ & $\mathrm{P}(6)$ \\
\hline & & & C (4) & $C(3)$ & $C(1)$ \\
\hline & & & $\mathrm{L}(2)$ & $\mathrm{L}(1)$ & L (7) \\
\hline \multirow{3}{*}{$\begin{array}{l}\text { South America } \\
\mathrm{n}=1\end{array}$} & & & & $\mathrm{P}(0)$ & $\mathrm{P}(1)$ \\
\hline & & & & $C(0)$ & $C(3)$ \\
\hline & & & & $\mathrm{L}(0)$ & $\mathrm{L}(1)$ \\
\hline \multirow{3}{*}{$\begin{array}{l}\text { South Asia } \\
n=3\end{array}$} & & & & & $\mathrm{P}(11)^{*}$ \\
\hline & & & & & $C(3)$ \\
\hline & & & & & $\mathrm{L}(7)$ \\
\hline
\end{tabular}

Noted: $\mathrm{n}=$ number of observations $-\mathrm{P}$ is the prime converged countries, $\mathrm{C}$ is the converging countries, and $\mathrm{L}$ is the little converged countries. Parantheses denotes the number of $\mathrm{k}$-combinations from a given set $\mathrm{S}$ of $\mathrm{n}$ element a-k combination. ${ }^{*}$ ) deals with a strong intra-blocs integration. ${ }^{* *}$ ) indicates a strong inter-blocs integration.

The linkage among economic blocs in the OIC looks closer, as most economic blocs are integrated into strong and moderate categories. Three economic blocs - South Asia, Middle East, and Africa - have a strong intra-bloc integration, while the other two blocs - ASEAN and South America - have a relatively weak integration. Within the South Asia bloc, Afghanistan has the weakest integration. Afghanistan experienced an appreciation of its currency, which sets it apart from the common depreciation trend of its neighbouring countries. A group of North African countries - Egypt, Libya, Nigeria, Mozambique, and Tunisia - have little integration with the rest of Africa. In ASEAN, only Indonesia has strong integration with other blocs.

\subsection{Testing the OCA Criteria}

Table 5 shows the simultaneous regression model that observes 946 pairs of countries. The t-test demonstrates five independent variables $(B C S, I N F, S I Z E$, TRADE, and DISTANCE) strongly associated with the OCA. The coefficient of determination (R2) is 60 percent and the significance level of the F test is less than 5 percent. These results are not much different from previous studies in Europe and Asia. A parallel finding by Calderon, Chong, and Stein (2003) proved 
that OCA criteria are relevant in explaining the variety of OCA in large (147 developing countries) observations. This study suggests that the geographic and economic disparities emerging in the OIC do not appear to be the main obstacle in forming a currency union.

The strong link between inflation similarity and the OCA in Islamic countries is widely documented (Echchabi et al., 2011; Bacha, 2006). Since most Islamic countries are not the price takers, their inflationary patterns are very sensitive to changes in foreign currency. Countries that have a very high inflation rate (above 10 percent) tend to experience low levels of integration, such as Iraq, Iran, Turkey, Nigeria, Mozambique, and Egypt. The business cycle synchronization has a positive impact on the OCA. Countries with a negative rate of growth, such as Brunei Darussalam, Iraq, and Libya, have a relatively weak integration. Interestingly, it has been asserted that co-movement of price is easier to achieve than output in most of the Islamic bloc (Fasano and Iqbal, 2003; Raison, 2011).

Table 5.

OLS Regression Estimation of OCA's Criteria

\begin{tabular}{|c|c|c|c|c|c|}
\hline \multicolumn{6}{|c|}{$\mathrm{SD}\left(\Delta \log \mathrm{e}_{\mathrm{ij}}\right)=-.065+12.490 \mathrm{SD}\left(\mathrm{BCS}_{\mathrm{ij}}\right)+.026 \mathrm{TRADE}_{\mathrm{ij}}-.004 \mathrm{SIZE}_{\mathrm{ij}}+.010 \mathrm{INFL}_{\mathrm{ij}}+.020$ DISTANCE $_{\mathrm{ij}}+\mathrm{e}$} \\
\hline \multirow[t]{2}{*}{ t-stat } & 12.417 & 8.75 & -3.411 & 28.836 & 2.451 \\
\hline & $(.000)^{* * *}$ & $(.000)^{* * *}$ & $(.001)^{* * *}$ & $(.000)^{* * *}$ & $(.014)^{* *}$ \\
\hline Observation $=784$ & & $R^{2}=0.597$ & & Adjusted $R^{2}=0.594$ & \\
\hline S.E $=0.083336$ & & $F=230.568$ & & F sig. $=0.000$ & \\
\hline
\end{tabular}

The size of the economy is associated with OCA, which is in line with McKinnon (1963), who suggests that large economic size is capable of maintaining a stable exchange rate. However, in Europe, the relationship between SIZE and OCA contradicts McKinnon's prediction, which might be because the GDP level of most European countries has reached optimum capacity, and a slight rise in GDP may encourage an overheating economy. This research indicates that the rise in trade in the OIC is not strong enough to push monetary integration. The imbalance of trading structures and little diversification of products among OIC countries is a common reason for the OIC (Al-Mawali, 2015). This study highlights that most Islamic nations are strongly integrated with each other even under severe geographical dispersion. Although proximity is the preferred condition, as the standard OCA theory and the graffiti model propose, it is not obligatory.

The weaknesses of this study arise from the OCA index itself. Whether an OCA is a good index depends on the characteristics of observation. For example, the poor economic blocs might produce the same level of OCA-index as the rich ones, even though their economic performance is clearly different. As long as the participating countries are in a similar condition, even under insufficient circumstances, they may be considered as feasible candidates. The similarity, therefore, might be translated into negative terms. This is why most Islamic nations are strongly integrated, even though their macroeconomic indicators are relatively disfavoured. 


\section{CONCLUSION}

This study concludes that the OIC is ready to form a currency union because 63 percent of the pairs of countries fall under the classification of prime converged and converging countries. Sixty pairs of countries have an OCA-index value equal to zero (very symmetrical volatility of exchange rate), and exist in three economic blocs - the GCC, West Africa, and Central Africa. The selected OCA's criteria present the best-fit criteria in explaining the OCA-index for the OIC. This study proves that price integration (inflation) is much easier to achieve than output integration (BCS and TRADE) in the OIC. This direction is out of step with the integration proposed by Balasa, and theoretically moves it from one of economic integration (output) to monetary integration (price).

This study provides an important contribution to the theory of OCA particularly in explaining the application of the OCA criteria in a large observation like the OIC. This study asserts that the economic and geographical heterogeneity, that is always considered to be a disadvantage, is not a serious hindrance to forming a currency union. The future prospects of the OIC's monetary union are promising since the socio-economic gaps among the OIC countries tend to be improving with the progress of time.

\section{REFERENCES}

Alesina, A., \& Barro, R. J. (2001). One Country, One Currency. Palo Alto, Calif.: Hoover Institution, 11-20.

Al-Mawali, N. (2015). Intra-Gulf Cooperation Council: Saudi Arabia Effect. Journal of Economic Integration, 3, 532-552.

Bacha, Ismath Obiyathullah. (2006). A Common Currency Area for MENA Countries? A VAR Analysis of Viability. International Journal of Emerging Market, 3(2), 197-215.

Bayoumi, T., \& Eichengreen, B. (1997). Even Closer to Heaven? an OptimumCurrency-Arean Index for European Countries. European Economic Review, 41, 761-770.

Calderon, C., Chong, A., \& Stein, E. (2007). Trade Intensity and Business Cycle Synchronization: are Developing Countries any Different? Journal of International Economics, 71, 2-21.

"Distance between Cities Places on Map", accessed July. (2016). Available at http:// www.distancefromto.net/

De Grauwe, P. (2006). What Have We Learnt about Monetary Integration since the Maastricht Treaty?. JCMS: Journal of Common Market Studies, 44(4), 711-730.

Echchabi, A., Sayid, O., Mahamad,I., Sorhiran,K., \& Zulkifli, Z. (2011). The implementation of Gulf Dinar and Its Possible Impacts, in Munich Personal RePEc Archive (MPRA, deposited 13:18, hosted by the Munich University Library in Germany, 1-24.

Falianty, T.A. (2006). Endogenitas dari Indikator Optimum Currency Area: Studi Empiris di Negara ASEAN. Jurnal Ekonomi dan Pembangunan Indonesia, 4 (2), $1-29$.

Fasano, U., \& Iqbal, Z. (2003). GCC Countries: From Oil Dependence to Diversification. International Monetary Fund. Publication services, Washington. D.C. 
Frankel, J.A., \& Rose, A. (1997). Is EMU More Justifiable Ex-post than Ex-ante?. European Economic Review, 41, 753-760.

Frankel, J.A., \& Rose, A. (1998). The Endogeneity of the Optimum Currency Area Criteria. The Economic Journal, 108, 1009-1025.

Ghosh, A. R., \& Wolf, H. C. (1994). How Many Monies? A Genetic Approach to Finding Optimum Currency Areas. National Bureau of Economic Research, No. W4805, $1-27$.

Gouveia, S., \& Correia, L. (2013). Trade Integration and Business Cycle Synchronization in the Euro Area: The Case of Southern European Countries. Journal of Economic Integration, 85-107.

Horvath, Julius. (2003). Optimum Currency Area Theory: A Selective Review. BOFIT Discussion Papers No. 15: Institute for Economies in Transition, 1-31.

Kamar, B. (2004). De Facto Exchange Rate Policies in the MENA Region: Toward Deeper Cooperation. Paper presented for the $11^{\text {th }}$ Annual Conference of The Economic Research Forum for the Arab countries, Iran and Turkey, December $16^{\text {th }}-18^{\text {th }}, 2004$, Beirut, Lebanon, 1-24.

Kandil, Magda. \& Trabelsi, M. (2010). Is the Announced Monetary Union in GCC Countries Feasible? A Multivariate Structural VAR Approach. Working Paper No 522: The Economic Research Forum (Erf), 1-19.

Kenen, P.B. (1969). The Theory of Optimum Currency Areas: An Eclectic View in R.A. Mundell and A.K. Swoboda. Monetary Problems of the International Economy. University of Chicago Press, 41-60.

Khan, M. S. (2009). The GCC Monetary Union: Choice of Exchange Rate Regime. Peterson Institute for International Economics Working Paper Series, No 09-1: Washington, D.C, 1-32.

Krugman, Paul. (1993). Lesson of Massachusetts for EMU, in Fransisco Toress and Francesco Giavazzi (eds). Adjustment and Growth in European Monetary Union. Cambridge University Press, 241-261.

Laabas, B., \& Limam, I. (2002). Are GCC Countries Ready for the Currency Union? Working Paper Series 0203. Arab Planning Institute, Kuwait, 1-32.

Lee, G. H. (2011). Gold Dinar for the Islamic Countries?. Economic Modelling, 28(4), 1573-1586.

Louis, R. J., Balli, F., \& Osman, M. (2008). Monetary Union amongst Arab Gulf Cooperation Council (AGCC) Countries: Does the Symmetry of Shocks Extend to the Non-Oil Sector?. In Economic Research Forum, $15^{\text {th }}$ Annual Conference, Cairo, Egypt, 1-26.

McKinnon, R. I. (1963). Optimum Currency Areas. The American Economic Review, 53(4), 717-725.

Mongelli, F. P. (2008). European Economic and Monetary Integration and the Optimum Currency Area Theory (No. 302). Directorate General Economic and Financial Affairs (DG ECFIN), European Commission, 1-58.

Mundell, R. A. (1961). A Theory of Optimum Currency Areas. The American Economic Review, 51(4), 657-665.

OIC. (2012). Exchange Rate Regimes in OIC Member Countries. OIC Outlook Series, SESRIC, 1-13.

Raison, O. (2011). The GCC Monetary Union: A Compromised Project? SSRN Electronic Journal. doi:10.2139/ssrn.1959887, 1-22. 
Rose, A. K. (2000). One Money, One Market: The Effect of Common Currencies on Trade. Economic Policy, 15(30), 08-45.

Ruzita, M.A., Hamid, Z., \& Norma, M. S. (2011). Are There Prospects for Future Economic Integration among Muslim Countries? Evidence from Selected OIC Countries. Journal of Economics and Management, 5(1), 179-215.

Saidi, N., \& Scacciavillani. F. (2010). The Case for Gold as a Reserve Asset in the GCC. Economic Noted, 11, 1-25.

SESRIC. (2015). Statistic and database (2015): available at http://www.sesrtcic.org/ Sheikh, K.A., Yusuf, Z., \& Aslam, M. (2013). Feasibility of a Monetary Union in the East African Community: A Structural Vector Auto Regression Model. Journal of Economics, Business, and Management, 1, 102-105.

Silva, J. S., \& Tenreyro, S. (2010). Currency Unions in Prospect and Retrospect. Annu. Rev. Econ., 2(1), 51-74.

Trimmer, P., \& McCelland, D. (2004). Economic Growth in the Muslim World: How Can USAID Help? Issue Paper Number 3, Bureau of Policy and Program Coordination, 1-53.

Uzonwanne, G. C. (2012). A Critical Review of the Theory of Optimum Currency Areas: Perspectives for a West African Single Currency. J Economics, 3(2), 73-81.

World Bank. (2015). New Country Classifications, http://data.worldbank.org/ news/new-country-classifications 
This page is intentionally left blank 